\title{
The Arboricultural and Economic Benefits of Formative Pruning Street Trees
}

\author{
C.M. Ryder and G.M. Moore
}

\begin{abstract}
Research was undertaken to determine the need for, and costs of, formative pruning recently planted street trees. Specimens of Corymbia citriodora (48), Platanus $\times$ acerifolia (104), Pyrus calleryana (79), Quercus palustris (65), and Ulmus parvifolia (52) were surveyed. Health was similar for all species, but form and structure varied. Data showed that codominant stems (68\%) and included bark (40\%) in the canopy or trunk were by far the most common structural defects.

Codominant stems were reported in $92 \%$ of all Ulmus parvifolia, $66 \%$ of Quercus palustris, $61 \%$ of Pyrus calleryana, $44 \%$ of Platanus $\times$ acerifolia, and $19 \%$ of Corymbia citriodora. The number of trees of a species that displayed no structural defects was $25 \%$ or less except for Corymbia citriodora with $60 \%$ showing no structural defects. The pruning required to rectify these structural defects was recorded and then multiplied by a time factor for pruning with secateurs (hand pruners), a handsaw, or a pole pruner. Total time was then converted to an economic cost using current labor market prices.

Platanus $\times$ acerifolia required the most work per tree with a final formative pruning cost of AUD $\$ 4.13$ followed by Ulmus parvifolia (\$3.25), Pyrus calleryana (\$2.76), Quercus palustris (\$1.62), and Corymbia citriodora (\$0.99). This compares with an average cost of $\$ 44.59$ per tree for structural pruning 20 year old trees. Formative pruning makes sound arboricultural and economic sense.

Key Words. Arboricultural Labor; Cost Benefit Analysis; Natural Target Pruning; Tree Management.
\end{abstract}

Directions on how, when, and what to prune have been published widely (Pirone et al. 1988; Gilman 1997; Harris et al. 1999; Gilman 2002; Joyce 2002). Knowledge of the role of branch bark ridges and collars has meant that pruning is done in a similar way to the tree's natural shedding processes (Moore 1992). This is consistent with good arboricultural practice and sound biological principles. By removing branches early, wound size is reduced as is the time taken to grow over the pruning cut by the production of callus and woundwood. The implementation of good formative pruning as part of a tree management plan is essential.

Formative pruning has long been advocated as good arboricultural management, but is too rarely practiced (Moore 2003). It can be defined as the selective removal of stems and branches early in a tree's life to create a safer, stronger, and more aesthetic structure. Many of the problems and defects of mature trees can be traced back to structural defects early in life. The loss of apical dominance and the occurrence of codominant stems have been linked to transplant shock, pest attack, and water stress in Fraxinus pennsylvanica (Oleksak et al. 1997). If these defects continue into maturity, the result may be a tree that is structurally weak (Gilman 2003), requiring significant remedial work to its structure that creates large wounds. This is more time-consuming than pruning lateral buds or small stems as they occur.

Although pruning costs have been calculated in various ways, there is little information on calculating the costs and benefits of formative pruning. If a tree is formatively pruned in the early stages of life, what will the cost-saving be if the same defects had not been rectified? For example, if a codominant stem is removed from a young tree at a height of three or four meters, with a pole pruner, what is the cost? If this same stem is left for 10 or 20 years and then has to be removed, or if one of the codominant stems has to be removed, what is the cost?

The purpose of this study was to look not only at how formative pruning can improve a tree's structure, but to quantify the financial benefits of removing structural defects early in a tree's life. Over time, the early removal of many hazards would allow more funds to be diverted from reactionary maintenance and removing hazards to the proactive management of the urban tree resource.

\section{METHODS}

Data were collected for five commonly planted street tree species in Melbourne, Australia: Corymbia citriodora, Platanus $\times$ acerifolia (syn $P$. hispida, P. hispanica), Pyrus calleryana cv chanticleer, Quercus palustris, and Ulmus parvifolia (Table $1)$. The trees selected were young (3-5 years of age) and under $6.5 \mathrm{~m}$ in height. Data were gathered on tree identification, health, structure, form, height, and canopy and stem structural defects. Tree form relates to the shape of a tree and, regardless of mature excurrent or decurrent form, a central trunk with radiating branches is what is often desired in urban street trees.

Excurrent form has a tendency to a central leader that remains superior to the lower branches resulting in a conical shape. In nature, most vigorous young trees, regardless of their adult form, have this form.

Decurrent form is where the lateral branches outgrow the main leader or trunk and form a more rounded, spreading canopy (Harris et al. 1999). 
When assessing the form of young trees, the excurrent form was used as a benchmark. Form was assessed using a five level rating system (Table 2). In young trees, ideally the branches should be evenly spaced vertically and radially up the stem. Looking on the tree from above, it should look like a spoked wheel with branches being small in relation to the trunk. On larger trees (trunk caliper of $\geq 100 \mathrm{~mm}$ ), at least some branches will be permanent and these should be well spaced and remain relatively small compared to the leader (Gilman 1997).

Structural defects on which data were collected (Table 3) were co-dominant stems, included bark, decay, deadwood and crossing or rubbing branches all of which may reduce the structural

Table 1. Summary of the number of trees assessed.

\begin{tabular}{ll}
\hline Species & Count \\
\hline Corymbia citriodora & 48 \\
Platanus $\times$ acerifolia & 104 \\
Pyrus calleryana & 79 \\
Quercus palustris & 65 \\
Ulmus parvifolia & 52 \\
\hline Total & 348 \\
\hline
\end{tabular}

Table 2. Tree form definitions.

\begin{tabular}{|c|c|}
\hline Rating & Definition \\
\hline Excellent & $\begin{array}{l}\text { A clear, strong, and straight leader firmly rooted in the ground. } \\
\text { A good level of taper up the stem, and a wide-angled branching } \\
\text { structure with even arrangement vertically and radially. }\end{array}$ \\
\hline Good & $\begin{array}{l}\text { A clear leader, possibly slightly crooked or weakened by laterals, } \\
\text { even spaced branches, and no major faults in the canopy. }\end{array}$ \\
\hline Fair & $\begin{array}{l}\text { A clear leader, with a possible lean or kink. Asymmetries in the } \\
\text { canopy or branch arrangement and possible a slight lean. }\end{array}$ \\
\hline Poor & $\begin{array}{l}\text { No clear leader, with possibly multiple leaders, leaning or a lost } \\
\text { leader. Heavy canopy asymmetry. }\end{array}$ \\
\hline Very poor & $\begin{array}{l}\text { No leader or multiple leaders. A heavy lean possibly with very } \\
\text { strong canopy asymmetry. Tree may have been vandalized. } \\
\text { Candidate for replacement. }\end{array}$ \\
\hline
\end{tabular}

rating of the tree (Matheny and Clark 1994; Harris et al. 1999). Most of these faults could be corrected with pruning. Details of the pruning cuts required with secateurs, handsaw, or pole pruner to remedy the structural defects in the canopies of the trees were recorded. Each pruning activity was timed and the costs associated with formative pruning calculated. A tree with good structure is highly unlikely to suffer significant failure while a tree with very poor structure has a high potential for failure.

For each specimen, the trunk caliper (at 100-150 mm above ground level), the location of the specimen, any comments specific to the tree, and the date of inspection were recorded. Factors such as height and trunk caliper were measured quantitatively, but tree structure and form were assessed visually using predetermined definitions employing ranking scales.

\section{Number of Cuts and Time Taken for Pruning}

Trees were inspected and structural defects were identified and recorded. Due to variations in the sizes of stems and branches, pruning was undertaken with secateurs (pruning shears), a handsaw, or with a pole pruner. An estimate of the number of pruning cuts required using the appropriate tool was made. Most of the structural defects observed could be corrected with formative pruning.

\section{Estimates of Time Required to Prune a Tree}

In order to assign a time to all works and achieve a total time for each tree, pruning trials were performed. For pruning with secateurs, ten repetitions of pruning a branch were conducted. Branch sizes ranged from $9 \mathrm{~mm}$ to $16 \mathrm{~mm}$. A total of twenty-six repetitions were completed for pruning a single branch with a handsaw. Branches with a diameter of less than $40 \mathrm{~mm}$ were pruned in one cut. Above $40 \mathrm{~mm}$, the branch was pruned using the undercut method (Harris et al. 1999). Branch size ranged from $19 \mathrm{~mm}$ to $90 \mathrm{~mm}$.

Twenty-five pruning repetitions were performed with the pole pruner. As size increased, the implement attached to the

Table 3. Structural defect definitions.

\begin{tabular}{ll}
\hline Fault & Definition \\
\hline Codominant stems & $\begin{array}{l}\text { Stems "Equal in size and relative importance, usually associated with either the trunks or stems or scaffold limbs...." (Harris et al. 1999) } \\
\text { Recorded if it occurred anywhere in the main stem, either low or high on the stem. }\end{array}$
\end{tabular}

Included bark Where bark is turned inwards at branch junctions instead of being pushed out (Harris et al. 1999), resulting in the branch or stem being weakly attached and prone to fracturing (Shigo 1991; Smiley 2003). This may occur anywhere in the canopy from small branches to codominant stems and stem should be pruned back or the whole tree removed.

Low branching Canopy lift required. Branches low on the stem of a tree that has established or branches encroaching on the road or pathway. The removal of low branches earlier rather than later reduces the wound on the trunk. If branches were encroaching on paths or roads, they were also canopy lifted. These were listed as a fault to be pruned.

Epicormic shoots "Sprouts upon the trunk" (Shigo 1991). They are not well attached to the trunk or stem and can present a hazard by breaking when they get larger.

Suckers Normally arise from roots at or below the soil surface. They are often shoots from rootstock to which the tree was grafted. Suckers can be vigorous and are not the desired cultivar.

Broken branches Branch may not completely break off and continue to grow with a weak point becoming a danger. Broken branches were pruned.

Broken stems Main stem is broken. Most of these trees needed replacement due to the structural defect that existed.

Deadwood Deadwood in the canopy requiring removal. Usually coincides with a low health rating.

Rubbing or crossing Branches rubbing against each other wound, which not only weakens the branch but provides an open wound for entry of pathogens. Removal eliminates the weak point; the tree can heal over quickly and the integrity of the tree is not compromised. Rubbing branches were pruned. 
end was changed from secateurs to the saw attachment. For branches with a diameter above $25 \mathrm{~mm}$, the saw had to be used in favor of the secateurs. Branch size ranged from $9 \mathrm{~mm}$ to $48 \mathrm{~mm}$ with an average size of $17 \mathrm{~mm}$. As the trees assessed for formative pruning were a maximum of $6.5 \mathrm{~m}$ tall, the use of the secateurs attachment was most common due to small diameter branches occurring high in the young tree canopy.

\section{Total Time and Cost}

Total time was determined by multiplying the number of pruning cuts by the time taken to perform the operation derived from the pruning trials. This was added to the inspection time and travel time to provide a total time required for work on each tree. As the distance between trees was not uniform, the time taken to walk between ten trees was measured and then divided by ten. The total time required per tree was the total of the time taken per pruning cut multiplied by the number of pruning cuts plus travel time between trees and the allocated inspection time of 30 seconds.

To determine a cost for formative pruning per tree, the amount of time required for pruning each tree was estimated. This involved counting how many cuts were required on the tree and then multiplying the number of cuts by a time factor. The use of a saw or secateurs attachment on the pole pruner took similar time. To assign a time to pruning a single branch with secateurs, a pruning trial was conducted. It was determined that branches up to 15 $\mathrm{mm}$ in diameter could be pruned using secateurs without strain. Pruning involved walking up to the tree, pruning off the branch with Felco ${ }^{\circledR}$ No. 2 secateurs, and removing it from the canopy and placing it on the ground. A sample of ten branches was selected and pruned. Few, if any, branches below $10 \mathrm{~mm}$ in size needed pruning.

Pruning with a handsaw encompassed a wide range of branch sizes. With $15 \mathrm{~mm}$ being the smallest, a branch of up to $100 \mathrm{~mm}$ could be pruned relatively easily. Due to large size differences, the research utilized two handsaws. The first was a small ARS $^{\circledR}$ turbocut handsaw with a $180 \mathrm{~mm}$ blade. This saw is lightweight, easy to use, and is good for small cuts as it fits easily into most branch crotches. This saw cuts easily up to $90 \mathrm{~mm}$ but a branch size limit of $50 \mathrm{~mm}$ was imposed.

The second, larger saw for branches of $50 \mathrm{~mm}$ and larger was a Wolf ${ }^{\circledR}$ garden handsaw designed for attachment to the Wolf multi-star ${ }^{\circledR}$ Vario 220-400 pole, which allows for use in pole pruning. The blade is approximately $350 \mathrm{~mm}$ long and good for larger pruning jobs. Branches up to $40 \mathrm{~mm}$ in diameter were pruned in one cut, but to avoid damage when pruning, the undercut method was used for branches over $40 \mathrm{~mm}$. An undercut was made approximately one quarter of the way through the branch and a second cut was made within $25 \mathrm{~mm}$ of the first cut on top of the limb and sawn until the branch broke. The third cut was made by cutting through the branch along the plane defined using the branch bark ridge (Harris et al. 1999).

Pruning requirements above approximately two meters (the height of the reach of an arborist) required the use of a pole pruner. The pole used was a Wolf multi-star Vario 220-400, which extends $2.2-4 \mathrm{~m}$ with handsaw and secateurs attachments. The handsaw used was the same as the large handsaw as previously described. The secateurs could cut a branch diameter of up to $40 \mathrm{~mm}$ but $30 \mathrm{~mm}$ was considered a more appropriate maximum. Larger branches over $30 \mathrm{~mm}$ were pruned with the handsaw. The largest trees surveyed in this trial were approximately five to six meters tall, meaning that seca- teurs were used most frequently. Equipment was easily carried in a carpenter's belt with the pole carried in hand. Due to differences in distance between trees along streets, a replicated trial was conducted to gauge the time taken to walk between two trees.

All pruning used Natural Target Pruning (NTP) methods (Shigo 1991). NTP removes branches taking into account the tree's natural branch shedding biology. An NTP cut is made beyond the plane defined by the branch bark ridge. If collars were visible the NTP cut was made close to but not through the collar (Standards Australia 2007). Once the data were collected, means, confidence intervals, uncorrected t-tests, ANOVA and regression were used to establish significance. Microsoft Excel and Minitab statistical package were used for the analyses.

\section{Cost of Labor and Mature Street Tree Pruning}

In order to compare the cost of formative pruning with structural pruning in mature trees, a group of 37 trees in a car park were pruned for the first time at an age of approximately 20 years. Pruning was undertaken to remove codominant stems, crossing, dead and rubbing branches, broken or split branches, and the removal of any branches below three meters from the ground. Assuming a known inflation rate of between 3\% and $5 \%$, a cost for structural pruning of the young trees assessed in this research could be estimated for comparison with the costs calculated for formative pruning. A further calculation was made costing two formative pruning cycles at three and six years for comparison with other management strategies.

In order to cost formative pruning, the market price on arboricultural labor was used. Two Melbourne-based arboricultural firms were consulted for quotations (Table 4). The average price was AUD $\$ 68.25$ per hour.

Table 4. Average price for arboricultural labor. Currency is represented in Australian dollars.

\begin{tabular}{ll}
\hline Business & Price \\
\hline Company A & $\$ 65 /$ hour per person \\
Company B & $\$ 71.50 /$ hour per person \\
Average & $\$ 68.25 /$ hour per person \\
\hline
\end{tabular}

\section{RESULTS}

There were no canopy structural defects in 78 trees, representing $22 \%$ of the sample. The remaining $78 \%$ displayed at least one fault, suggesting that there is a need for formative pruning in all tree management plans. Over the range of trees sampled, work with the pole pruner was required most (Table 5). The average number of cuts required by the pole pruner was more than the work for the secateurs and handsaw combined.

The occurrence of codominant stems $(68 \%)$ throughout the canopy or trunk of the tree was the greatest fault, followed by included bark (40\%) (Table 5). When both occurred together, the fault was magnified by the included bark in codominant stems, which is a major weakness in tree structure (Harris et al. 1999). Low branching in $17 \%$ of the trees was a reflection of a need for a canopy lift to accommodate either vehicular or pedestrian access. Rubbing and broken branches (12\% and $14 \%$, respectively) were common; however, epicormic shoots, broken stems, and deadwood occurred at low levels. The low value of deadwood is a reflection that the street trees were young and in good health. There was wide variation be- 
tween species in the occurrence and frequency of structural defects. Ulmus parvifolia had the highest percentage of codominant stems, whilst Corymbia citriodora had the lowest (Table 6).

\section{Estimates of Time Required to Prune a Tree}

In order to assign a time to all works and achieve a total time for each tree, pruning trials were performed.

\section{Secateurs Pruning}

An average time of eight seconds was derived to prune a branch (Table 7). The time recorded included approaching the tree, holding the branch, pruning it, removing it, and placing the branch on the ground. The results showed that the time taken to prune with secateurs was linearly related to branch size according to the equation $\mathrm{t}=1.0084 \mathrm{~s}-4.9706\left(\mathrm{R}^{2}=0.8345\right)$, where $\mathrm{t}=$ time in seconds to prune a branch and $\mathrm{s}=$ size of the branch in millimetres. As branch size increased, so did the time taken to remove it.

\section{Handsaw Pruning}

The average time taken to prune a branch was 24.8 seconds (Table 7). This was rounded to 25 seconds. The average diameter for this trial was $36 \mathrm{~mm}$, which was an appropriate size for formative pruning. The regression equation, $t=0.9581 \mathrm{~s}-$ $10.126\left(\mathrm{R}^{2}=0.8826\right)$ provided evidence of a linear relationship between the size of the branch and the time taken to remove it.

\section{Pole Pruner Pruning}

The average time taken to prune a branch using the pole pruner was 26.12 seconds, rounded to 26 seconds (Table 7). There was no simple linear relationship between size of branch and time taken to prune (regression equation, $\mathrm{t}=0.3051 \mathrm{~s}+20.725$, $\mathrm{R}^{2}=0.0836$ ) due the compounding factor of height. As the height increased, branches took longer to remove because it was increasingly difficult to use the pole pruner with increasing length. Table 7 summarizes the results of the time trials including the number of repetitions, branch sizes pruned and the amount of time required.

Table 5. Height, caliper, structural defects, and the average number of pruning cuts required for all trees.

\begin{tabular}{|c|c|c|c|c|c|}
\hline & \multirow[t]{2}{*}{ Mean height $(\mathrm{m})$} & \multirow[t]{2}{*}{ Mean caliper $(\mathrm{mm})$} & \multicolumn{3}{|c|}{ Mean number of pruning cut } \\
\hline & & & Secateurs & Handsaw & Pole pruner \\
\hline All species & 4.3 & 102.9 & 0.9 & 1.9 & 2.2 \\
\hline \multicolumn{6}{|c|}{ Structural defects as a percentage of tree sample } \\
\hline & Codominant stems & Included bark & Low branching & Broken branches & Rubbing branches \\
\hline All species & 68.4 & 40.2 & 18.1 & 14.4 & 12.4 \\
\hline \multicolumn{6}{|c|}{ Structural defects as a percentage of tree sample } \\
\hline & Epicormic Shoots & Broken Stem & Dead Wood & No structural defe & \\
\hline All species & 2.9 & 2.3 & 1.1 & 22 & \\
\hline
\end{tabular}

Table 6. Height, caliper, structural defects, and the average number of pruning cuts required for each species.

\begin{tabular}{|c|c|c|c|c|c|c|}
\hline & Species & Corymbia citriodora & Platanus $\times$ acerifolia & Pyrus calleryana & Quercus palustris & Ulmus parvifolia \\
\hline $\begin{array}{l}\text { Number of } \\
\text { trees sampled }\end{array}$ & & 48 & 104 & 79 & 65 & 52 \\
\hline Dimensions & $\begin{array}{l}\text { Mean height }(\mathrm{m}) \\
\text { Mean caliper }(\mathrm{mm})\end{array}$ & $\begin{array}{l}4.3 \\
71.1\end{array}$ & $\begin{array}{l}4.6 \\
124.7\end{array}$ & $\begin{array}{l}3.7 \\
70.9\end{array}$ & $\begin{array}{l}5.2 \\
132.6\end{array}$ & $\begin{array}{l}3.8 \\
100.1\end{array}$ \\
\hline $\begin{array}{l}\text { Number of } \\
\text { pruning cuts }\end{array}$ & $\begin{array}{l}\text { Mean secateurs } \\
\text { Mean handsaw } \\
\text { Mean pole pruner } \\
\text { Total average cuts }\end{array}$ & $\begin{array}{l}0.6 \\
0.3 \\
0.2 \\
1.0\end{array}$ & $\begin{array}{l}0.7 \\
2.9 \\
4.0 \\
7.6\end{array}$ & $\begin{array}{l}1.5 \\
1.9 \\
1.9 \\
5.3\end{array}$ & $\begin{array}{l}0.4 \\
0.4 \\
1.4 \\
2.2\end{array}$ & $\begin{array}{l}1.4 \\
3.2 \\
1.7 \\
6.3\end{array}$ \\
\hline $\begin{array}{l}\text { Structural } \\
\text { defects as a } \\
\text { percentage of } \\
\text { species sample } \\
\text { number }\end{array}$ & $\begin{array}{l}\text { Codominant stems } \\
\text { Included bark } \\
\text { Low branching } \\
\text { Rubbing branches } \\
\text { Broken branch(es) } \\
\text { Broken stem } \\
\text { Epicormic shoots } \\
\text { Deadwood } \\
\text { No structural defects }\end{array}$ & $\begin{array}{l}18.75 \\
16.7 \\
8.3 \\
2.1 \\
4.2 \\
2.1 \\
0.0 \\
2.1 \\
60.4\end{array}$ & $\begin{array}{l}44.2 \\
43.3 \\
10.6 \\
2.9 \\
16.3 \\
3.8 \\
1.9 \\
1.0 \\
3.8\end{array}$ & $\begin{array}{l}60.8 \\
36.7 \\
23.1 \\
16.5 \\
5.1 \\
0.0 \\
3.8 \\
0.0 \\
25.3\end{array}$ & $\begin{array}{l}66.2 \\
3.1 \\
41.3 \\
20.0 \\
10.8 \\
0.0 \\
1.5 \\
0.0 \\
21.5\end{array}$ & $\begin{array}{l}92.3 \\
34.6 \\
17.3 \\
13.5 \\
9.6 \\
3.8 \\
3.8 \\
0.0 \\
3.8\end{array}$ \\
\hline
\end{tabular}

Table 7. Time trials.

\begin{tabular}{|c|c|c|c|c|c|}
\hline Type & $\begin{array}{l}\text { Number of } \\
\text { cuts made }\end{array}$ & $\begin{array}{l}\text { Branch size } \\
\text { range }(\mathrm{mm})\end{array}$ & $\begin{array}{l}\text { Average branch } \\
\text { size }(\mathrm{mm})\end{array}$ & $\begin{array}{l}\text { Time taken } \\
\text { to prune }(\mathrm{s})\end{array}$ & $\begin{array}{l}\text { Average time } \\
\text { of pruning (s) }\end{array}$ \\
\hline Secateurs & 10 & $9-16$ & 12.8 & $5-13$ & 8.0 \\
\hline Hand saw & 26 & 19-93 & 36.5 & $11-90$ & 24.8 \\
\hline
\end{tabular}




\section{Total Time and Cost}

Using the mean pruning cuts values for each species (Table 6), a total time was determined (Table 8). Average time to walk between two trees was 5.9 seconds, rounded to six seconds (Table 9). The total time required per tree was the total of the time taken per pruning cut multiplied by the number of pruning cuts plus travel time between trees and the allocated inspection time of 30 seconds. For a particular species, the total time taken for pruning was calculated using the equation:

[1] $\quad \mathrm{T}=8 \mathrm{~S}+25 \mathrm{H}+26 \mathrm{P}+36$

where $\mathrm{T}=$ total time (seconds), $\mathrm{S}=$ time to prune with secateurs (s), $\mathrm{H}=$ time to prune with handsaws (s), $\mathrm{P}=$ time to prune with pole pruner $(\mathrm{s}), 36(\mathrm{~s})=$ constant (inspection plus travel time).

The total cost for each species per tree was calculated by multiplying the final time by the labor cost (Table 10). Table 11 provides the $95 \%$ confidence interval for the mean pruning cost per species per tree.

\section{Comparison with Pruning Mature Trees}

In contrast to an average cost for formative pruning of $\$ 2.79$ per tree (Table 10), pruning mature trees is expensive. The average cost of pruning 37 eucalypts at age 20 years was $\$ 44.59$ each. Allowing for rates of inflation of between 3\% and 5\% per annum, it was estimated that in 20 years the trees formatively pruned today would cost between $\$ 78$ and $\$ 112$ to prune, if action had not been taken to remedy structural defects (Table 12).

When this is compared to the cost of two formative pruning cycles after three and six years, totalling \$6.40-\$7.00 (Table 13), there is a 13-18 fold increase. Whilst this is a significant saving, formative pruning would not be the only pruning cost incurred. It is expected that there would still be future pruning required; however, this should be significantly diminished with trees that have good structure.

\section{DISCUSSION}

Analysis of data indicates there is a strong rationale for pruning when trees are young. Assessment of 348 trees showed that only $22 \%$ displayed no structural defects and that there was at least one defect or fault in the remaining $78 \%$ of trees. The structural defects varied in their numbers, with codominant stems (Table 6) that have a weaker attachment than branches being the most common fault in the trees (Shigo 1991; Moore 1992; Gilman 2002; Smiley 2003). The problem is exacerbated by the presence of included bark, which makes codominant stems prone to split, posing significant hazard and safety risks in streets. Of the trees assessed, 35\% displayed codominant stems and included bark. The remaining trees that were codominant but without included bark could develop included bark over time. As trees grow, the stems expand incrementally every year (Harris et al. 1999), causing the two codominant stems to become included. Removal of codominant stems in young trees should be a high priority in any formative pruning regime.

Pruning trials were designed to allow processes to be timed (Table 7). Pruning with secateurs over an acceptable range of branch diameters showed a clear linear relationship $\left(\mathrm{R}^{2}=0.83\right)$ between size and time required to remedy a defect-the smaller the branch the less time it took to prune. This may be important when planning formative pruning schedules. For instance, if pruning is scheduled with an average branch size of $10 \mathrm{~mm}$ instead of $15 \mathrm{~mm}$, the average pruning time would fall from approximately 10 seconds to 5 seconds, which represents a significant saving for a large number of trees. The $9 \mathrm{~mm}-16 \mathrm{~mm}$

Table 8. Total time required for each species per tree.

\begin{tabular}{|c|c|c|c|c|c|c|}
\hline \multirow[b]{2}{*}{ Species } & \multicolumn{3}{|c|}{ Time average per tree (seconds) } & \multirow[b]{2}{*}{$\begin{array}{l}\text { Travel and } \\
\text { inspection time (s) }\end{array}$} & \multirow[b]{2}{*}{$\begin{array}{l}\text { Total } \\
\text { time }(\mathrm{s})\end{array}$} & \multirow[b]{2}{*}{$\begin{array}{l}\text { Total time } \\
\text { per tree }(\mathrm{hr}\end{array}$} \\
\hline & Secateurs & Handsaw & Pole pruner & & & \\
\hline Corymbia citriodora & 4.6664 & 6.25 & 5.4158 & 36 & 52.3322 & 0.0145 \\
\hline Platanus $\times$ acerifolia & 5.9232 & 72.355 & 103.7504 & 36 & 218.0286 & 0.0606 \\
\hline Pyrus calleryana & 11.9496 & 48.1025 & 49.3662 & 36 & 145.4183 & 0.0404 \\
\hline Quercus palustris & 3.4464 & 9.23 & 36.8004 & 36 & 85.4768 & 0.0237 \\
\hline Ulmus parvifolia & 11.0768 & 79.3275 & 45.0008 & 36 & 171.4051 & 0.0476 \\
\hline
\end{tabular}

Table 9. Travel time between trees (seconds).

\begin{tabular}{lll}
\hline Repetition & Time taken $(\mathrm{s})$ & Average time $(\mathrm{s})$ \\
\hline 1 & 60 & 6 \\
2 & 58 & 5.8 \\
& Total & 5.9 \\
\hline
\end{tabular}

Table 10. Total cost for each tree species. Currency is represented in Australian dollars.

\begin{tabular}{lll}
\hline Species & Total time $(\mathrm{hr})$ & Cost per tree $(\$)$ \\
\hline Corymbia citriodora & 0.0145 & $\$ 0.99$ \\
Platanus $\times$ acerifolia & 0.0606 & $\$ 4.13$ \\
Pyrus calleryana & 0.0404 & $\$ 2.76$ \\
Quercus palustris & 0.0237 & $\$ 1.62$ \\
Ulmus parvifolia & 0.0476 & $\$ 3.25$ \\
$\quad$ Average Cost & & $\$ 2.79$ \\
\hline
\end{tabular}

Table 11. Ninety-five percent confidence interval for the cost of pruning each species. Currency is represented in Australian dollars.

\begin{tabular}{lllll}
\hline Species & Count & Mean cost & SE mean & $95 \%$ CI \\
\hline Corymbia citriodora & 48 & $\$ 0.99$ & 0.0808 & $\$ 0.83, \$ 1.15$ \\
Platanus $\times$ acerifolia & 104 & $\$ 4.13$ & 0.185 & $\$ 3.77, \$ 4.49$ \\
Pyrus calleryana & 79 & $\$ 2.76$ & 0.224 & $\$ 2.32, \$ 3.20$ \\
Quercus palustris & 65 & $\$ 1.62$ & 0.091 & $\$ 1.44, \$ 1.80$ \\
Ulmus parvifolia & 52 & $\$ 3.25$ & 0.248 & $\$ 2.76, \$ 3.74$ \\
\hline
\end{tabular}

Table 12. Projected costs assuming an inflation rate of $3 \%-$ $5 \%$. Currency is represented in Australian dollars.

\begin{tabular}{llll}
\hline Year & $3 \%$ & $4 \%$ & $5 \%$ \\
\hline 1 & $\$ 44.59$ & $\$ 44.59$ & $\$ 44.59$ \\
20 & $\$ 78.19$ & $\$ 93.94$ & $\$ 112.68$ \\
\hline
\end{tabular}


size range estimate is practical and effective for the use of secateurs. Below this size the branches are inconsequential and take little time to prune, and above this size the difficulty of pruning increases. The use of a handsaw over this size may also reduce the risk of musculoskeletal disorders developing in arborists.

Pruning using a handsaw also showed a clear linear relationship $\left(\mathrm{R}^{2}=0.88\right)$ between branch size and pruning time (Table 7). The data obtained were mostly for branches in the $20 \mathrm{~mm}-40 \mathrm{~mm}$ range with an average time of 25 seconds taken to prune an average branch diameter of $36 \mathrm{~mm}$. In broad scale tree management, knowledge of branch sizes would help in preparing tenders and contracts. Many larger branch removals would significantly increase the cost of pruning.

Unlike secateurs and handsaws, the use of a pole pruner did not return a linear regression $\left(\mathrm{R}^{2}=0.08\right)$, due the confounding factor of height (Table 7). The higher the branch to be pruned, the longer it took to remove, regardless of whether secateurs or handsaws were used. With trees up to $6.5 \mathrm{~m}$, however, the number of higher large branches was limited.

The total time required to prune trees included an allocated inspection time averaging 30 seconds per tree. While this seemed reasonable, small trees took significantly less time while larger trees took longer. The time taken to walk from tree to tree (6 seconds) was included in the total time.

The time taken to formatively prune varied across species with Corymbia citriodora taking only 52 seconds on average, while Platanus $\times$ acerifolia averaged 218 seconds (Table 8). To convert these times to a current market value, the time was multiplied by the cost of labor (Table 10).

In order to compare the cost of formative pruning with structural pruning in a mature tree, structural pruning costs need to be known. A group of 37 trees in a car park were pruned for the first time at an age of approximately 20 years. The average cost per tree was $\$ 44.59$. Assuming an inflation rate of between $3 \%-5 \%$, the cost of this structural pruning of mature trees is projected to be approximately $\$ 80-\$ 110$ in 20 years (Table 12). Delaying pruning makes it more difficult to correct structural defects by pruning, and so the cost increases accordingly. Furthermore, the potential for developing good structure later in the tree's life is reduced.

Formative pruning is designed to remove or prevent many of the structural defects that structural pruning tries to fix. An average cost of $\$ 2.79$ to prune a tree is substantially less than pruning a tree at age 20 . This is not to say that formative pruning will completely erase the need for structural pruning in the future. It should however reduce the need substantially. Formative pruning should be seen as a sound economic investment, improving trees into maturity.

Corymbia citriodora had the lowest number of required cuts and time for all species. An average cost of $\$ 1$ suggested that they are very economical to maintain. While there was a high incidence of codominant stems with included bark, their early removal would rectify this fault. Alternatively, failure to prune could result in the tree needing to be replaced. A cost benefit analysis could be performed to decide which management approach to take.
Platanus $\times$ acerifolia had the highest number of cuts and longest time for all species. More than three and a half minutes were required for each specimen, totaling more than $\$ 4$ per tree. They are a tree commonly planted in streets for their tolerance to adverse conditions, but there is quite a lot of work maintaining them to maturity. These trees were very healthy and vigorous and their rapid growth may have led to a loss of apical dominance and hence the need for greater levels of pruning. Cultivar selection may improve the requirement for formative pruning in the species; however, it is clear that some pruning to establish a strong framework is required. This highlights the need for formative pruning within nurseries before trees are consigned for planting.

Pyrus calleryana had a high time value, despite its smaller size. Many of the trees were prone to codominant stems and included bark. Approximately two and a half minutes was required per tree, costing $\$ 2.76$. There is variation in this species with different cultivars developing different canopy structures. The more fastigiate form, Pyrus calleryana cv chanticleer, demonstrated higher numbers of structural defects. The decision to use this tree should be seriously considered as it provided the lowest cost benefit ratio of ten street tree species in the United States (McPherson 2003).

Quercus palustris was in general a well structured and healthy species. Although it was on average the tallest species sampled, work required on this tree was the second lowest, with an average cost of $\$ 1.62$. Little pruning was required to establish a strong trunk as $Q$. palustris naturally formed an excurrent shape.

Although the average height of Ulmus parvifolia was the second lowest for all species, the recorded works and time required were the second highest at nearly three minutes per tree, at a cost of $\$ 3.25$. This tree did not naturally form a straight trunk and a lot of work was required to develop one. The tree had a tendency to produce many large lower limbs, often with included bark, which would have to be removed. These trees required a lot of work with handsaws to remove lower limbs. Creating a well-structured and mature $U$. parvifolia appears from this study to require a substantial input of resources.

A proper formative pruning regime may require at least two cycles. Assuming good quality planting stock has been used, pruning at planting shouldn't be required. If the trees were then pruned after three years and again at seven years, the total cost should be approximately $\$ 6.40-\$ 7.00$ per tree (Table 13). This cost makes formative pruning a cost effective exercise that could potentially improve the structure of the trees in urban environments, and represent a significant saving for large tree populations. Pruning in cycles would see formative pruning crews established for this explicit purpose.

Table 13. Total cost for two formative pruning cycles for trees that have been formatively pruned prior to delivery from the nursery. Currency is represented in Australian dollars.

\begin{tabular}{llll}
\hline Year & $3 \%$ & $4 \%$ & $5 \%$ \\
\hline 1 & - & - & - \\
4 & $\$ 3.05$ & $\$ 3.14$ & $\$ 3.23$ \\
7 & $\$ 3.33$ & $\$ 3.53$ & $\$ 3.74$ \\
Total & $\$ 6.38$ & $\$ 6.67$ & $\$ 6.97$ \\
\hline
\end{tabular}




\section{CONCLUSION}

Formative pruning is a cost effective way of reducing structural defects in trees and improving the quality of the structure of street tree populations. Overwhelmingly, the major structural fault recorded was the presence of codominant stems in the canopy or trunk, often exacerbated by the presence of included bark. All other structural defects recorded were in much smaller numbers. A small amount of work when the trees are young, in the order of 1-4 minutes, would reduce many problems associated with mature tree failure.

The use of current labor market prices is a way of costing works, which allows the transformation of the time used into a monetary value appropriate for today's and projected markets. With a range of $\$ 1.00-\$ 4.13$, depending on species, it makes the prospect of formative pruning small trees on a large scale not only attractive but effective economically, especially when compared to the cost of remedial pruning works on mature street trees.

The result of not formative pruning the trees, is a vicious cycle of removing poor trees, structurally pruning other trees, replanting and not having time to formatively prune new trees. In order to break this cycle, all new trees should be pruned on a cycle of two to four years, at least two or three times when young. Providing a strong structural framework in the beginning will reduce the work required in the future.

Acknowledgments. The authors acknowledge the assistance of Mr. J. Summers (City of Hume) who provided data on the pruning of 37 , 20-year-old eucalypts. Mr. T. Greenwood (The Tree Works) and Mr. P. Kenyon (Tree Tactics) are thanked for their assistance in providing estimated labor costs for formative pruning trees and data on pruning 20 -year-old trees. Ms. E. Moore is thanked for her suggestions for improving the manuscript.

\section{LITERATURE CITED}

Gilman, E.F. 1997. Trees for Urban and Suburban Landscapes. Delmar Publishers, Albany, New York, U.S.

Gilman, E.F. 2002, An Illustrated Guide to Pruning, 2nd edition. Delmar Publishers, Albany, New York, U.S.

Gilman, E.F. 2003. Branch-to-stem diameter ratio affects strength of attachment. Journal of Arboriculture 29(5):291-4.

Harris, R.W., J.R. Clark, and N.P. Matheny. 1999. Arboriculture. Integrated Management of Landscape Trees, Shrubs, and Vines. 3rd edition, Prentice Hall, New Jersey, U.S.

Joyce, D. 2002. Pruning and Training Plants. A Complete Guide, Octopus Publishing, London, England.

Matheny, N.P., and J.R. Clark. 1994. A Photographic Guide to the Evaluation of Hazard Trees in Urban Areas. International Society of Arboriculture, Champaign, Illinois, U.S.

McPherson, E.G. 2003. A benefit-cost analysis of ten street tree species in Modesto, California, U.S. Journal of Arboriculture 29(1):1-7.

Moore, G.M. 1992. Branch Attachment and Pruning, in Scientific Management of Plants in the Urban Environment. VCAH Burnley, Melbourne, Australia.

Moore, G.M. 2003. Crown Thinning and Weight Reduction: Beginning the Analysis, Conference Proceedings. International Society of Arboriculture Australian Chapter, Adelaide, Australia.

Oleksak, B., M. Kmetz-Gonzalez, and D.K. Struve. 1997. Terminal bud cluster pruning promotes apical control in transplanted shade tree whips. Journal of Arboriculture 23(4):147-53.

Pirone, P.P., J.R. Hartman, M.A. Sall, and T.P. Pirone. 1988. Tree Maintenance. 6th edition, Oxford University Press, U.S.

Shigo, A. 1991. Modern Arboriculture: A Systems Approach to the Care of Trees and Their Associates, Shigo and Trees, Associates.

Smiley, E.T. 2003. Does Included Bark Reduce the Strength of Codominant Stems? Journal of Arboriculture 29(2):104-5.

Standards Australia, 2007. Australian Standard AS-4373, Pruning of Amenity Trees, Standards Australia, Sydney.

Cameron Ryder

Senior Consulting Arborist

Homewood Consulting

23 Worrell Street

Nunawading, Victoria, Australia 3131

Gregory Moore, Ph.D. (corresponding author)

Senior Research Associate

Burnley College

University of Melbourne

500 Yarra Boulevard

Richmond, Australia 3121

gmoore@unimelb.edu.au 
Résumé. Des recherches ont été menées afin de déterminer les besoins ainsi que les coûts associés à la taille de formation chez les arbres récemment plantés. Des spécimens de Corymbia citriodora (48), Platanus $\times$ acerifolia (104), Pyrus calleryana (79), Quercus palustris (65) et Ulmus parvifolia (52) ont été étudiés. La condition de santé était similaire pour toutes les espèces, mais la forme et la structure variaient. Les données ont montré que les cas de tiges codominantes $(68 \%)$ ainsi que d'écorce incluse (40\%) dans la couronne ou le tronc étaient de loin les défauts structuraux les plus courants.

La présence de tiges codominantes a été observée chez $92 \%$ des Ulmus parvifolia, $66 \%$ des Quercus palustris, $61 \%$ des Pyrus calleryana, $44 \%$ des Platanus $\times$ acerifolia et $19 \%$ des Corymbia citriodora. Le nombre d'arbres d'une espèce spécifique qui ne présentait pas de défaut structural était de $25 \%$ ou moins, à l'exception du Corymbia citriodora avec $60 \%$ des arbres sans défaut structural. La taille requise pour rectifier ces défauts structuraux a été enregistrée et multiplié par un facteur de temps selon que le travail était exécuté avec un sécateur à main, une égoïne ou un émondoir. Le temps total était par la suite converti en coût économique en fonction des coûts moyens de la maind'œuvre sur le marché.

Le Platanus $\times$ acerifolia était l'espèce qui exigeait le plus de travail par arbre avec un coût formel final d'élagage de 4,13\$, suivi de l'Ulmus parvifolia (3,25\$), du Pyrus calleryana $(2,76 \$)$, du Quercus palustris $(1,62 \$)$ et du Corymbia citriodora $(0,99 \$)$. Ceci se compare avec un coût moyen de 44,59\$ par arbre pour un élagage de formation chez des arbres âgés de 20 ans. La taille de formation s'avère être un choix logique en termes arboricole et économique.

Zusammenfassung. Hier wurde ein Forschungsprojekt begonnen, um den Bedarf und die Kosten von Erziehungsschnitt an kürzlich gepflanzten Strassenbäumen zu erfassen. Es wurden Exemplare von Corymbia citriodora (48), Platanus $\times$ acerifolia (104), Pyrus calleryana (79), Quercus palustris (65), und Ulmus parvifolia (52) untersucht. Der Gesundheitszustand war bei allen gleich, aber die Form und Struktur wich voneinander ab. Die erhobenen Daten zeigten, dass kodominante Stämme (68\%)(Zwiesel) und eingewachsene Rinde (40\%) in der Krone oder im Stammbereich die häufigsten strukturellen Defekte waren.

Kodominante Stämme wurden bei $92 \%$ aller Ulmus parvifolia, $66 \%$ der Quercus palustris, $61 \%$ der Pyrus calleryana, $44 \%$ der Platanus $\times$ acerifolia, und 19\% der Corymbia citriodora gefunden. Die Anzahl von Bäumen innerhalb einer Art, die keinerlei strukturelle Defizite aufwies, betrug bei $25 \%$ oder weniger, während bei Corymbia citriodora $60 \%$ keinerlei strukturelle Defekte aufwiesen. Der erforderliche Rückschnitt, um diesen Defekt zu korrigieren, wurde aufgezeichnet und mit einem Zeitfaktor für Schnitte mit der Rosenschere, Handsäge oder Stangensäge multipliziert. Die Gesamtzeit wurde anschließend unter Zuhilfenahme üblicher Löhne in ökonomische Kosten konvertiert.

Platanus $\times$ acerifolia erforderten die meiste Arbeit pro Baum mit Schnittkosten von AUD \$4.13 gefolgt durch Ulmus parvifolia (\$3.25), Pyrus calleryana (\$2.76), Quercus palustris (\$1.62) und Corymbia citriodora (\$0.99). Das wird verglichen mit den durchschnittlichen Kosten für den Rückschnitt eines 20jährigen Baumes von $\$ 44,59$ pro Baum. Der Erziehungsschnitt ist aus baumpflegerischer und ökonomischer Sicht sinnvoll.

Resumen. La investigación se llevó a cabo para determinar la necesidad y costos de poda formativa de árboles recientemente plantados. Fueron evaluados especímenes de Corymbia citriodora (48), Platanus $\times$ acerifolia (104), Pyrus calleryana (79), Quercus palustris (65), y Ulmus parvifolia (52). La salud fue similar en todas las especies, pero la forma y la estructura variaron. Los datos mostraron que los tallos codominantes $(68 \%)$ y corteza incluida (40\%) en la copa o el tronco fueron por mucho los defectos estructurales más comunes.

Los tallos codominantes fueron reportados en $92 \%$ de todos los $\mathrm{Ul}$ mus parvifolia, 66\% de Quercus palustris, 61\% de Pyrus calleryana, $44 \%$ de Platanus $\times$ acerifolia, y $19 \%$ de Corymbia citriodora. El número de árboles de una especie que mostraron defectos no estructurales fue $25 \%$ o menos excepto para Corymbia citriodora con $60 \%$ sin defectos estructurales. La poda requerida para rectificar estos defectos estructurales fue registrada para luego multiplicar por el factor tiempo para poda con pinzas de mano, serrotes, o pértigas. El tiempo total fue entonces convertido a un costo económico usando precios de labor del mercado actuales.

Platanus $\times$ acerifolia requirió el mayor trabajo por árbol con un costo final formativo por árbol de AUD \$4.13 seguido por Ulmus parvifolia (\$3.25), Pyrus calleryana (\$2.76), Quercus palustris (\$1.62), y Corymbia citriodora (\$0.99). Esto se compara con un costo promedio de $\$ 44.59$ por árbol para poda estructural de árboles de 20 años de edad. Las podas formativas tienen sentido arboricultural y económico. 